\title{
Leaflet phenotypic plasticity in three woody species in two strata of a gallery forest
}

Jamile dos Santos ${ }^{\mathrm{ii}}$, Ricardo Antonio Marenco ${ }^{2 \mathrm{iD}}$, Wendy Carniello Ferreira ${ }^{\mathrm{iD}}$, Daniela Pereira Dias ${ }^{1 * i D}$

'Federal University of Jataí, Jataí, Goiás, Brazil ${ }^{2}$ Instituto Nacional de Pesquisa da Amazônia, Manaus, Amazonas, Brazil

\section{SILVICULTURE}

\section{ABSTRACT}

Background: Along the vertical canopy profile, natural light availability is variable and may induce leaves morphophysiological changes due to phenotypic plasticity. Morphological changes in juvenile and adult leaflet of compound leaves of plant species is still poorly understood, including in woody species of gallery forests. The present study evaluated the leaflet morphophysiological characteristics and plasticity index of three woody species in canopy and understory leaves in a gallery forest.

Results: All morphophysiological characteristics varied within species (Myracrodruon urundeuva Allemão, Copaifera langsdorffii Desf. and Tapirira guianensis Aubl.). The leaflets of canopy trees showed significantly higher values of petiole length (PL) and diameter (PD), leaflet thickness (fresh - FT and dry DT), specific leaf mass $(S L M)$, in relation to understory leaflets. On the other hand, relative water content (RWC) did not change between adult trees and saplings, except for T. guianensis. The plasticity index of leaflet characteristics varied significantly within species. Plasticity index of three morphophysiological characteristics (PL, PD and DT) varied between species. PL and PD had the highest plasticity index values across species, whereas RWC had the lowest plasticity.

Conclusion: Plasticity index of the tree species associates these leaflet morphophysiological traits (PL, PD and DT) with variations in the physical environment between strata of a gallery forest.

Keywords: Brazilian savanna, leaf structure, specific leaf mass, relative water content

\section{HIGHLIGHTS}

Leaflets morphological traits are influenced by light variations of a gallery forest.

Petiole traits (length and diameter) and dry leaflet thickness vary between species.

SANTOS, J.; MARENCO, R. A.; FERREIRA, W. C.; DIAS, D. P. Leaflet phenotypic plasticity in three woody species in two strata of a gallery forests. CERNE, v.27, e-102645, doi: 10.1590/01047760202127012645 


\section{INTRODUCTION}

A type of riparian forest, known as gallery forest, covers the humid areas in the Brazilian savanna, occupying the banks of streams and small rivers, forming closed corridors above them (Ribeiro and Walter, 2008). Although the gallery's forests occupy less than $10 \%$ of the savanna area, they are home to an enormous diversity of flora and fauna (Oliveira-Filho and Ratter, 2002). Basic differences of the manually measured variables between formations (forested savanna, woodland savanna (rainy and dry) highlight that the gallery forest had the tallest canopy, greatest trunk volumes and biomass, even when there is a lower density of individuals (Zimbres et al., 2020). Besides, the Brazilian Forest Code regulates the protection of Riparian Zones, which are categorized as riparian permanent protection areas (RPPAs). According Forest Code, RPPAs prescribes a minimum 30 meters forest buffer around narrow streams (less than $10 \mathrm{~m}$ wide), to ensure water supply, erosion control, and biodiversity conservation (Federal Law 12.651/2012). In this context, it is important to increase knowledge about gallery forest, both from the biotic and abiotic component. The first includes the survival and maintenance of gene flow between populations of animal species, while the abiotic part comprises hydrological functions, protection of the riparian zone, filtration of sediments and nutrients, control of nutrient and chemical inputs to water courses, erosion control of channel banks and the control of changes in temperature in the aquatic ecosystem (Durigan and Silveira 1999; Silva et al., 2017).

Microclimatic conditions below the closed canopy of gallery forests also provide shading for topsoil (Ribeiro and Walter, 2008; Gignoux et al., 2016). It is well known that tropical forests with denser canopies reduce incidence of solar radiation to plants in the lower stratum of the forest (Mendes et al., 2013). In heterogeneous light environments, leaves from different forest strata may have altered leaf morphophysiological characteristics (Rozendaal et al., 2006; da Silveira et al., 2015). Morphophysiological characteristics such as stomatal density, dry mass, total thickness, leaf angle, leaf shape and petiole and internode length (da Silveira et al., 2015; Marenco et al., 2017; Boeger et al., 2018) may alter fitness across species and determine divergence among species of the forest ecosystem. These changes promoted by the environment can be crucial for the survival of understory plants under heterogeneous conditions.

Despite that, morphological changes in juvenile and adult leaflet of compound leaves of plant species is still poorly understood, including in woody species of gallery forests. The structure of compound leaves provides flexibility for morphological change by variation in shape, size and arrangement of leaflets (Sanches et al., 2009; Klingenberg et al., 2012). These characteristics are important for increasing light capture and maintaining photosynthetic rates, especially in understory plants. The differences between mature leaves from a young plant and mature leaves from a fully grown tree of the same species may suggest that the microclimate influences leaf formation during plant growth.
The ability to adjust the expression of various phenotypes according to environmental conditions is known as phenotypic plasticity (Nicotra et al., 2010; Gratani, 2014). Quantifying the phenotypic plasticity is important to understand how species can or cannot adjust to environmental changes (Valladares et al., 2000). Considering changes in natural light conditions, it has been hypothesized that species may modify morphophysiological characteristics, and consequently they present high phenotypic plasticity in order to survive in different light environments (Rozendaal et al., 2006; Marenco et al., 2017). Thus, the aim of this study was to evaluate the leaflet morphological characteristics and plasticity index of Myracrodruon urundeuva Allemão (Anacardiaceae), Copaifera langsdorffii Desf. (Leguminosae) and Tapirira guianensis Aubl. (Anacardiaceae) in canopy and understory leaves of a gallery forest, at County Jataí, State Goiás, Brazil.

\section{MATERIAL AND METHODS}

The study was carried out in a fragment of a Gallery forest $\left(17^{\circ} 55^{\prime} \mathrm{S}\right.$ to $17^{\circ} 56^{\prime} \mathrm{S}$ and $51^{\circ} 42^{\prime} \mathrm{W}$ to $\left.51^{\circ} 42^{\prime} \mathrm{W}\right)$, at County Jataí, State Goiás, Brazil, with an approximate area of 10.9 ha. The study area is located in the Cerrado, with an mean annual rainfall of $1,645 \mathrm{~mm}$ and an mean annual temperature of $23.7^{\circ} \mathrm{C}$, located at an altitude of $670 \mathrm{~m}$ (INMET, 2017). The climate in the region is tropical savanna (Awa in the Köppen classification). The predominant soil is a Dystrophic Red Latosol (Oxisol), with a very clay texture; it is deep, very porous and permeable, and with low susceptibility to erosion (Scopel and Silva, 2001).

In the study area, canopy trees (adult tree) and small understory saplings of three species with compound leaves were selected. The selected species were Myracrodruon urundeuva, Copaifera langsdorffii e Tapirira guianensis. These woody species were selected in a previous survey based on their Importance Value Index obtained from a phytosociological study. Five replications per species were collected between 7:00 and 9:00 h from each forest stratum (canopy and understory) and five leaflets per leaf were selected. Morphological data were obtained in November 2014 (rainy season). Saplings height and diameter were obtained with a millimeter rule and calipers, respectively (Tab. 1). In adult trees, diameter at breast height $(1.30 \mathrm{~m}$ above the ground) was determined with mechanical calipers and height was estimated using a retractable ruler (Tab. 1).

The plant material (branches) was collected in the study area, properly packed in plastic bags and then taken to the laboratory for the determination of morphophysiological leaflet characteristics. From each individual studied, five leaflets fully expanded were selected. They had an adequate phytosanitary condition and were located in the middle third of the branches.

Petiole length and diameter ( $\mathrm{PL}$ and $\mathrm{PD}, \mathrm{mm}$ ) data were measured using digital calipers. The fresh and dry leaflet thickness (FT and DT, mm) was measured with a digital micrometer. Specific leaf mass $\left(\mathrm{g} \cdot \mathrm{cm}^{-2}\right)$ was calculated as the ratio of dry mass $(\mathrm{g})$ to leaf disc area $-\mathrm{cm}^{2}(\mathrm{SLM}=\mathrm{DM} / \mathrm{A})$. Relative water content (RWC) was determined by extracting 
Tab 1 Tree diameter $(\mathrm{cm})$ and height $(\mathrm{m})$ of three species from canopy and understory of a Gallery forest fragment at County Jataí, State Goiás, Brazil.

\begin{tabular}{lcccc}
\hline \multirow{2}{*}{ Species } & \multicolumn{2}{c}{ Canopy cover } & \multicolumn{2}{c}{ Understory cover } \\
\cline { 2 - 5 } & Diameter $(\mathrm{cm})$ & Height $(\mathrm{m})$ & Diameter $(\mathrm{cm})$ & Height $(\mathrm{m})$ \\
\hline Myracrodruon urundeuva & $11.0-24.0$ & $17.0-20.0$ & $0.19-0.94$ & $0.40-1.40$ \\
Copaifera langsdorffii & $14.4-30.0$ & $18.0-31.0$ & $0.20-1.02$ & $0.51-1.95$ \\
Tapirira guianensis & $13.6-40.2$ & $21.0-24.0$ & $0.29-0.81$ & $0.60-1.20$ \\
\hline
\end{tabular}

two leaf discs per leaf, with a hollow metal cylinder with $14.15 \mathrm{~mm}$ in diameter. The weight of fresh matter (FM) of the samples was obtained with a precision balance (accuracy of $0.0001 \mathrm{~g}$ ). Then, the leaf discs were transferred to a 35 $\mathrm{mm}$ Petri dish, where they were submerged for 36 hours in water, in order to obtain the weight of the turgid material (TM). Subsequently, the discs were oven-dried at $65^{\circ} \mathrm{C}, 72 \mathrm{~h}$, to determine the dry matter (DM). The RWC was determined by the formula: RWC (\%) = 100 (FM - DM)/(TM - DM).

The phenotypic plasticity index was obtained from the leaflet morphological characteristics, calculated as the maximum value minus the minimum value divided by the maximum value, with a scale varying between 0 and 1 , as proposed by Valladares et al. (2000). The phenotypic plasticity index was calculated for each species, considering the different forest strata, and for each morphological characteristic.
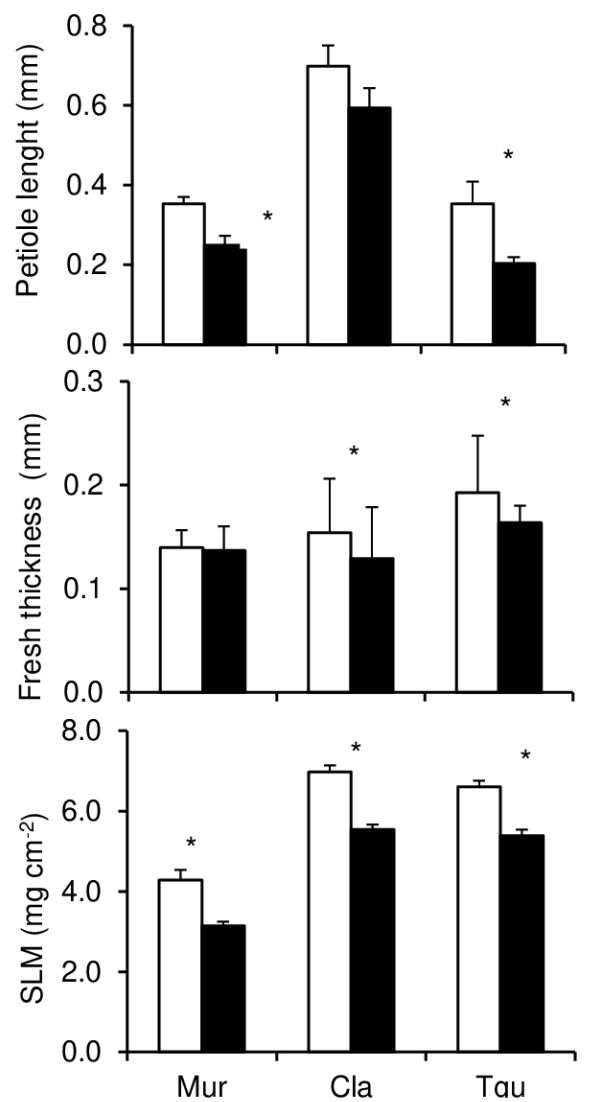

Mean values and respective standard deviations were calculated for the variables studied. Leaflet morphological characteristics were compared using the t-test $(a=0.05)$. The data were subjected to analysis of variance (ANOVA) and transformed when they did not meet the statistical assumptions (dividing the observed value by the maximum value found in each species). The morphological characteristics were correlated with each other using Pearson's correlation. Rbio statistical analysis software was used.

\section{RESULTS}

The respective of forest stratum, morphological leaflet characteristics showed differences between species $(p<0.01$; Fig. 1), except for dry thickness (DT) in canopy
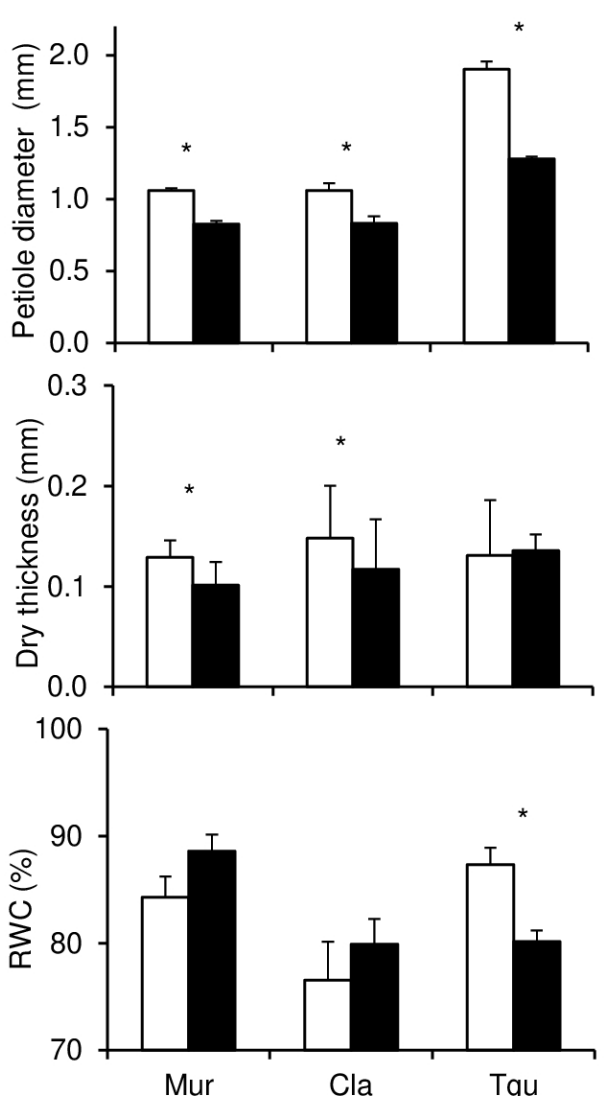

Fig. 1 Relationship between canopy opening (CO), leaf area index (IAF) and diffuse fraction of photosynthetically active absorbed radiation (FAPARdif) and the number of harvested trees (DBH $>30 \mathrm{~cm})$. * indicates a significant Person linear coefficient $(p=0.05)$. 
leaflets ( $p=0.16, F=2.11$ ) and the relative water content (RWC) of canopy ( $p=0.33, F=1.21)$ and understory leaflets $(p=0.09, F=2.90)$.

C. langsdorffi (Cla) petiole was smaller in canopy and understory leaflets (Fig. 1), in relation to others species. Tapirira guiannesis (Tgu) presented larger petiole diameter (PD) and fresh thickness (FT) in canopy and understory leaflets. Petiole diameter (DT) of $M$. urundeuva (Mur) from understory leaflets was lower than that of the other species, as well as the specific leaf mass (SLM) of this species irrespective of forest stratum. The RWC was higher in the saplings than in adult tree, except in T. guianensis.

Petiole length $(\mathrm{PL})$ was greater in canopy leaflets than in understory leaflets (Fig. 1), except in C. langsdorffii. In $M$. urundeuva and T. guianensis, PL from understory leaflets decreased 29.4 and $42.5 \%$, respectively, in comparison with canopy leaflets. In each species studied, PD showed significant difference $(p<0.05)$ between canopy and understory leaflets (Fig. 1). In comparison with canopy leaflets, PD decreased $22.1 \%$ in $M$. urundeuva, $21.6 \%$ in C. langsdorffi and $32.7 \%$ in T. guianensis in understory leaflets.

Fresh thickness (FT) of M. urundeuva leaflets showed no significant changes $(p>0.05)$ in different forest strata (Fig. 1), while C. langsdorffi showed an increase of $19.37 \%$ and T. guianensis $17.68 \%$ in canopy leaflets compared with understory leaflets. Taking the understory as the base line, DT increased $27.45 \%$ in $M$. urundeuva, $26.38 \%$ in C. langsdorffii and for T. guianensis there was no significant difference between strata (Fig. 1).

In the three studied species, SLM varied significantly ( $p<0.05$ ) between leaflets of the forest strata, with the understory leaflets showing lower SLM than canopy leaflets (Figure 1). In canopy leaflets, SLM was $36.17 \%$ higher for
M. urundeuva, $25.87 \%$ for C. langsdorffii and $22.49 \%$ for $T$. guianensis in comparison with understory leaflets.

Relative water content (RWC) in canopy and understory leaflets did not differ between species (Fig. 1, $p$ $=0.00$ ), the values ranged from 76.6 to $88.6 \%$.

We found a positive correlation between SLM and $\mathrm{PL}, \mathrm{PD}, \mathrm{FT}$ or DT (Tab. 2), but there was no significantly correlation between RWC and other variables (Tab. 2). The correlation was greater between FT and PD (0.84).

In all species, the plasticity index of morphophysiological leaflet characteristics varied significantly within species (Fig. 2, p = 0.00). PL and PD plasticity had the greater values and RWC, FT and DT plasticity the lower.

The plasticity index for FT, SLM and RWC did not differ between species (Fig. 3), however the plasticity index for PL, PD and DT varied between species (Figure 3). While C. langsdorffii (Cla) leaflets presented greater plasticity index in relation to PL and PD leaflets, $T$ guianensis (Tgu) leaflets showed lower plasticity index in dry thickness.

Tab. 2 Pearson's correlation coefficient between morphophysiological characteristics analyzed (petiole length and diameter ( $\mathrm{PL}$ and $\mathrm{PD}, \mathrm{mm}$ ), leaflet thickness (fresh and dry - FT and DT, mm), specific leaf mass (SLM, $\left.\mathrm{mg} \cdot \mathrm{cm}^{-2}\right)$ and relative water content (RWC, \%).

\begin{tabular}{ccccccc}
\hline & $P L$ & $P D$ & $F T$ & DT & SLM & RWC \\
\hline$P L$ & - & & & & & \\
$P D$ & -0.22 & - & & & & \\
$F T$ & -0.18 & $0.84^{* *}$ & - & & & \\
$D T$ & 0.27 & $0.40^{*}$ & $0.52^{* *}$ & - & & \\
$S L M$ & $0.53^{* *}$ & $0.47^{* *}$ & $0.57^{* *}$ & $0.69^{* *}$ & - & \\
RWC & -0.16 & 0.12 & 0.12 & -0.13 & -0.05 & - \\
\hline
\end{tabular}
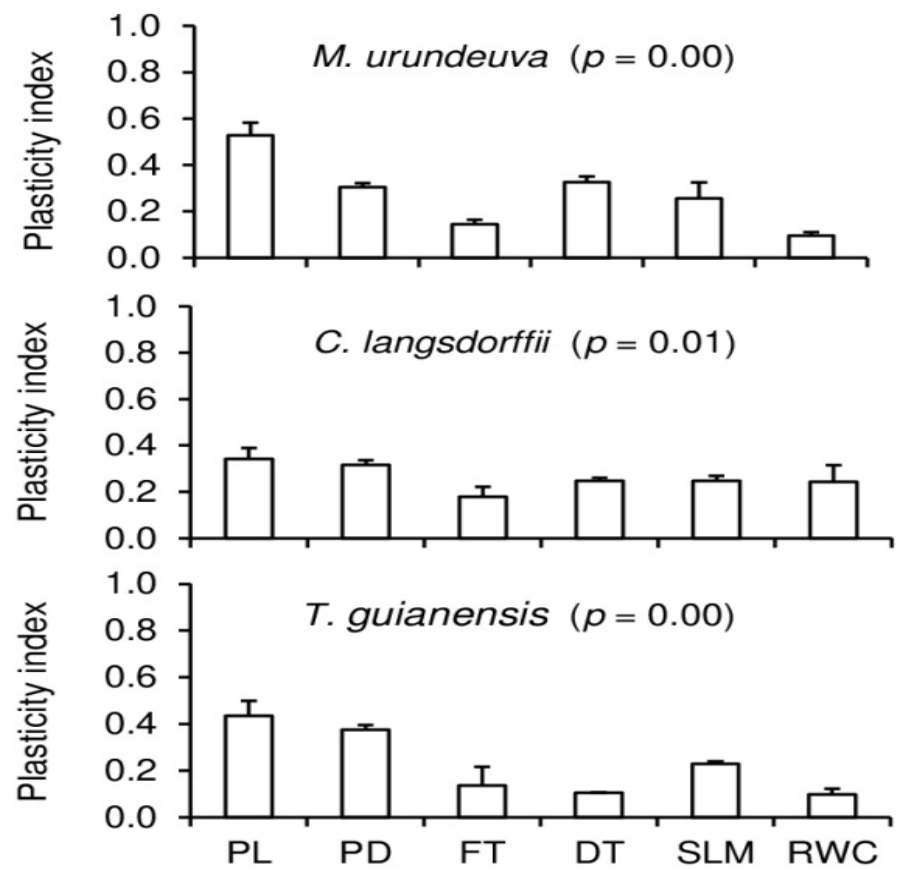

Fig. 2 Phenotypic plasticity index of leaflet morphological characteristics within species (Petiole diameter and length - PD and $\mathrm{PL}$, leaflet thickness (fresh and dry FT and DT), specific leaf mass - SLM and relative water content - RWC) of three tree species (Myracrodruon urundeuva Allemão, Copaifera langsdorffii Desf. and Tapirira guianensis Aubl.) in canopy and understory of a gallery forest fragment. 

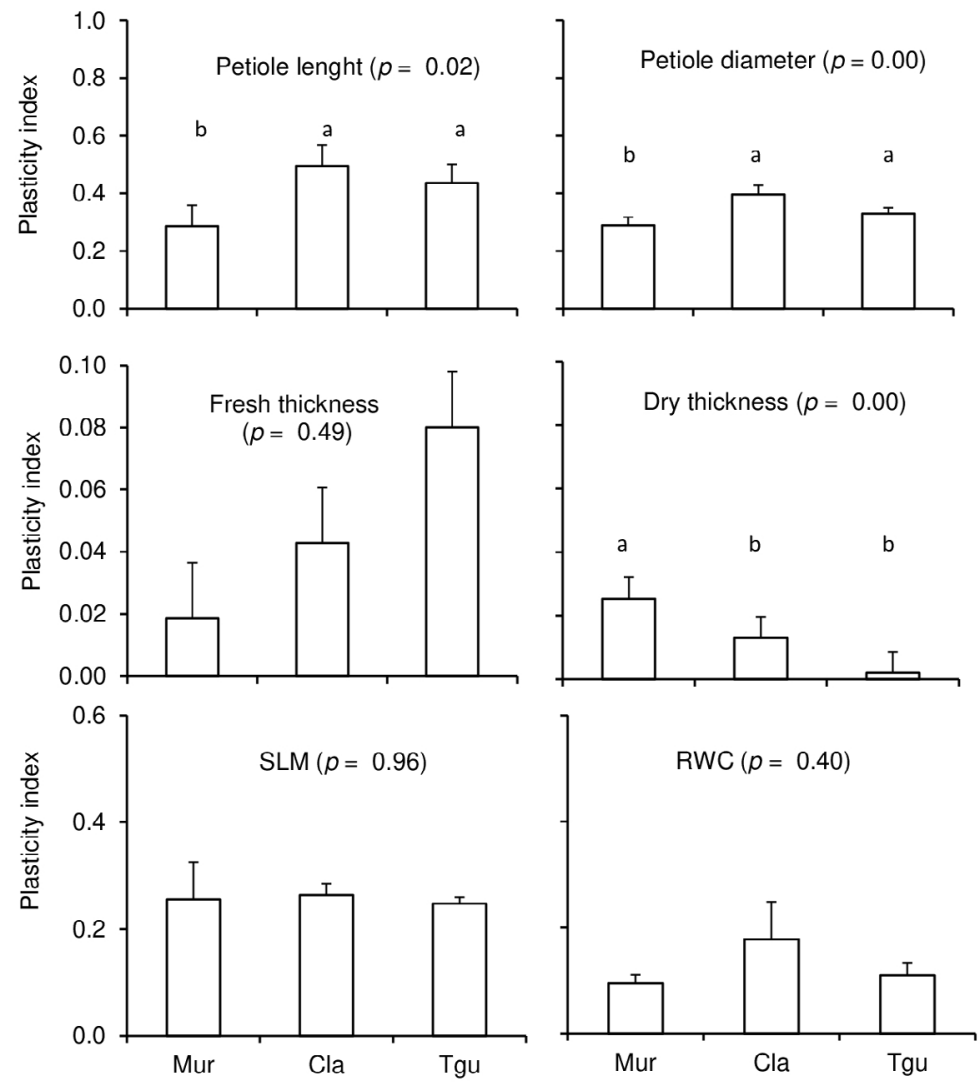

Fig. 3 Phenotypic plasticity index of leaflet morphological variables between species (Petiole length and diameter, leaflet thickness (fresh and dry), specific leaf mass and relative water content) of three tree species (Myracrodruon urundeuva - Mur, Copaifera langsdorffii - Cla e Tapirira guianensis - Tgu) in canopy and understory of a gallery forest fragment.

Petiole length $(\mathrm{PL})$ had the highest plasticity index values (0.44) across species (Fig. 4), whereas RWC had the lowest plasticity (0.13).

\section{DISCUSSION}

Myracrodruon urundeuva, Copaifera langsdorffii and Tapirira guianensis leaflets in canopy and understory of a gallery forest fragment exhibited differences in morphophysiological characteristics. Our results are in agreement with those reported by Barros et al. (2012), Marenco et al. (2017), suggesting genetic differences. On the other hand, mean values for dry thickness (DT) of canopy leaflets did not differ significantly between species, which led us to conclude that this trait is less responsive to variations in environmental factors. The relative water content (RWC) values, in canopy and understory leaflets, did not differ between species, which suggests that data collected during the rainy season led all species to have high RWC. Goldsmith et al. (2013) hypothesize that foliar water uptake occurs independent of phylogeny, morphology

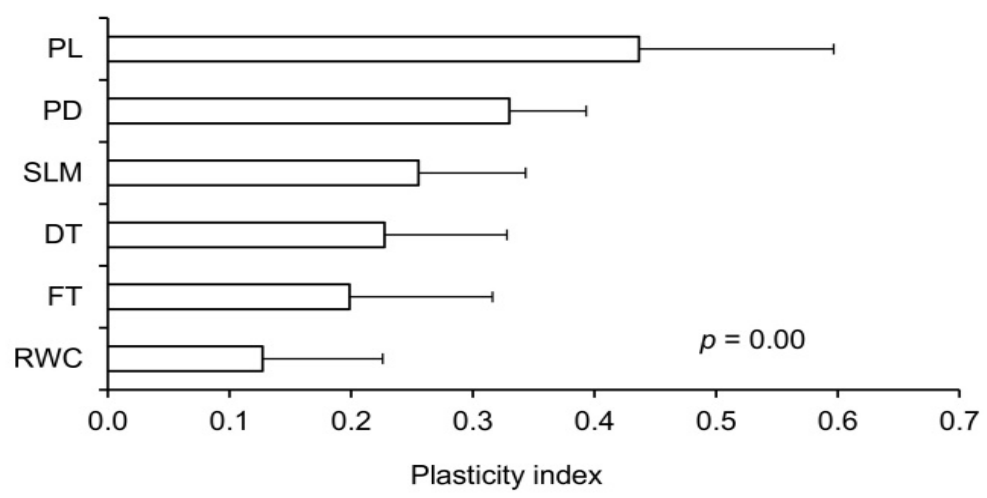

Fig. 4 Phenotypic plasticity index of leaflet morphological variables across species (Petiole length and diameter - PL and PD, leaflet thickness (fresh and dry - FT and DT), specific leaf mass - SLM and relative water content - RWC) of three tree species presents in canopy and understory of gallery forest. 
and growth habit; however, more information is required to actually identify plant anatomy traits that favor this process. To maximize their photosynthetic rates, tropical plants may have modified their leaf anatomy to cope with frequent leaf wetness. By contrast, leaf anatomy traits in savanna sites are more likely to have evolved to conserve water (Aparecido et al., 2017).

Rainfall alone does not define water availability to trees (Adams et al., 2019). In the tropics especially, seasonal distributions of rainfall and evaporative demand ensure that soil water storage plays a major role in year-round water availability, which in turn is reflected in seasonal variation in photosynthetic productivity of tropical forests (Guan et al., 2015). Broadly speaking, tropical regions with pronounced dry seasons (typically savanna ecosystems) have seasonal changes in leaf area and transpiration, when compared with regions that have more uniform rainfall (Guan et al., 2015). In this respect, even in tropical rainforest changes in transpiration rates can also be observed over the year depending on environmental conditions (Antezana-Vera and Marenco, 2020).

Morphophysiological characteristics varied among strata (Boeger et al., 2004; da Silveira et al., 2015; Marenco et al., 2017). In comparison with canopy leaflets, petiole length and diameter (PL and PD), fresh and dry thickness of leaflets (FT and DT), and specific leaf mass (SLM) were lower in understory leaflets, in the present study. As expected, SLM increase with leaf development for all species, hence it is used as an indicator of leaf softness, with low values of SLM indicating soft leaves (Kursar and Coley, 2003). Understory leaves had higher leaf area and lower leaf dry mass and thickness, in comparison with canopy leaves. Under low light availability, tree species have developed strategies to capture diffuse light (Boeger et al., 2006). In Caesalpinia echinata Lam., for example, SLM of leaflets increased from $38.6 \mathrm{~g} \cdot \mathrm{m}^{-2}$ at the sapling stage to $55.0 \mathrm{~g} \cdot \mathrm{m}^{-2}$ in adult trees (Sanches et al., 2009), with is consistent with higher leaves thickness in canopy leaves.

Regarding the forest profile, leaves of tree species grown in the lower stratum of the forest presents leaf thickness lower than leaves from upper strata (da Silveira et al. 2015). With respect to anatomical leaf traits, leaf thickness of sun and shade leaves of Corylus avellana L. (Betulaceae) were 97.6 and $77.7 \mu \mathrm{m}$ thick, respectively (Catoni et al., 2015a). In the first leaves of Eugenia hiemalis Cambess. (Myrtaceae), leaf thickness increased with increasing light availability (Nascimento et al., 2015). An increase in leaves thickness is often associated with an increase in palisade parenchyma thickness and values of net photosynthetic rates (Valladares et al., 2000; Catoni et al., 2015a; da Silveira et al., 2015, Marenco et al., 2017). Canopy leaves have more photosynthetic cells per unit leaf area, as well as greater amounts of photosynthetic enzymes, which indicates that canopy leaflets had mesophyll cells that are well developed. In contrast, shade leaves had more spongy parenchyma and the leaves are thinner (Sanches et al., 2009; Catoni et al., 2015b; Marenco et al., 2017).

However, contrary to our initial expectations, PL and PD did not increase with reduction in light availability. Beside contributing to avoid overlapping of leaves (self- shading) and providing mechanical support, the length and diameter of the petiole may reflect the influence of light interception. King (1999) found shorter petiole in leaves with thinner leaves, and generally, leaves of individuals in the understory have thinner leaves, because they have been established under low light conditions.

Relative water content (RWC) has been commonly used to assess the level of water stress, as it directly reflects changes in photosynthetic rates (Lin et al., 2015). RWC reduction to values below $70 \%$ slows the photosynthetic $\mathrm{CO}_{2}$ assimilation rate, promoting a decline in the photosynthetic leaf rate due to stomatal closure (Lawlor and Cornic, 2002). In cells, the reduction in CRA affects cell physiology in several ways, including changes in the position of intracellular organelles, and modifications in transport channels and enzyme biochemistry, as well as cell wall contraction (Lambers et al., 1998; Lawlor and Cornic, 2002).

Just as FT was related to PD, all leaflet characteristics revealed a relationship with SLM. Under different strata conditions, especially light-related influences, the relationships were expected, which was previously discussed. Contrary to expectations, RWC was not significantly related to leaflet characteristics, probably because RWC data showed little variation between strata.

Phenotypic plasticity was expressed in leaflets from different forest strata in response to different light availability and ontogeny. Its expression occurs differently in petioles (length and diameter) and leaf dry thickness. Phenotypic plasticity can be valuable in climate change studies, because genetic adaptation is slow (Valladares et al., 2014; Duputié et al., 2015). Plant morphological plasticity may be greater than physiological and anatomical plasticity index (Catoni et al., 2015a). The mean plasticity index of petiole length and diameter were higher than other morphophysiological characteristics, with no significant differences between species. Our results showed that species studied respond differently to changing light environments, affecting the success of understory species in forest dynamics.

In their study based on the 25 leaf traits, dos Anjos et al. (2015) identified the traits most related to high and low plasticity on young plants of five tropical tree species for six months under different light conditions. Catoni et al. (2015a) showed the high plasticity index (0.33) of C. avellana plants growing in different light conditions. This study shows plasticity index related to shade tolerance of M. urundeuva, C. langsdorffii and T. guianensis, which were responsive to light variations.

\section{CONCLUSION}

Morphological characteristics of $M$. urundeuva, C. langsdorffii and T. guianensis leaflets of canopy and understory grown saplings are influenced by light variations, of the heterogeneous environment of a gallery forest fragment. The phenotypic plasticity of morphological variables associated with petiole traits (length and diameter) and dry leaflet thickness vary between species. 


\section{ACKNOWLEDGEMENT}

Thanks to the Fundação de Apoio a Pesquisa do Estado de Goiás (FAPEG, 05/2012) for supporting this research..

\section{AUTHORSHIP CONTRIBUTION}

\author{
Project Idea: DPD \\ Funding: DPD \\ Database: JS, WCF, DPD \\ Processing: JS, DPD \\ Analysis: JS, RAM, DPD \\ Writing: JS, RAM, DPD \\ Review: RAM, WCF, DPD
}

\section{REFERENCES}

ADAMS, M. A.; BUCKLEY, T. N.; TURNBULL, T. L. Rainfall drives variation in rates of change in intrinsic water use efficiency of tropical forests. Nature Communications, v. 10, n. 1, p. 1-8, 2019

ANTEZANA-VERA, S.A., MARENCO, R.A. Sap flow rates of Minquartia guianensis in central Amazonia during the prolonged dry season of 20152016. Journal of Forest Research, v. 31, n. 4, 2020

APARECIDO, L. M. T.; MILLER, G. R.; CAHILL, A. T.; MOORE, G. W. Leaf surface traits and water storage retention affect photosynthetic responses to leaf surface wetness among wet tropical forest and semiarid savanna plants. Tree Physiology, v. 37, n. 10, p. 1285-1300, 2017.

BARROS, F. DE V.; GOULART, M. F.; SÁ TELLES, S. B.; LOVATO, M. B. VALLADARES, F. Phenotypic plasticity to light of two congeneric trees from contrasting habitats: Brazilian Atlantic Forest versus cerrado (savanna). Plant Biology, v. 14, n. 1, p. 208-215, 2012.

BOEGER, M. R. T., ALVES, L. C.; NEGRELLE, R. R. B. Leaf morphology of 89 tree species from a Lowland Tropical Rain Forest (Atlantic Forest) in South Brazil. Brazilian Archives of Biology and Technology, v. 47, n. 6, p. 933-943, 2004

BOEGER, M. R. T.; KAEHLER, M.; MELO JR, J. C. F DE ; GOMES, M. Z. ; OLIVEIRA L. S.; CHAVES, C. R. M. ; SCHOTTZ, E. S. Estrutura foliar de seis espécies do sub bosque de um remanescente de Floresta Ombrófila Mista. Hoehnea, v. 33, n. 2, p. 521-531, 2006.

BOEGER, M. R. T: PILATTI, D. M: LIMA C. S. DE; ALVARENGA, A. M. S. B. DE; PERETO, S. C. A. DA S. Leaf architecture and symmetry of understory tree species of an Araucaria forest. Acta Scientiarum. Biological Sciences, v. 40, n. 1, p. 1-8, 2018.

CATONI, R.; GRANATA, M. U.; SARTORI, F.; VARONE, L.; GRATANI, L. Corylus avellana responsiveness to light variations: morphological, anatomical, and physiological leaf trait plasticity. Photosynthetica, v. 53, n. 1, p. 35-46, 2015 a.

CATONI, R.; GRATANI, L.; SARTORI, F.; VARONE, L.; GRANATA, M. U. Carbon gain optimization in five broadleaf deciduous trees in response to light variation within the crown: correlations among morphological, anatomical and physiological leaf traits. Acta Botanica Croatica, v. 74, n. 1, p. 71-94 2015b.

DA SILVEIRA, T. I., BOEGER, M. R. T., MARANHO, L. T. Functional leaf traits of 57 woody species of the Araucaria Forest, Southern Brazil. Brazilian Journal of Botany, v. 38, n. 2, p. 357-366, 2015.

DOS ANJOS, L: OLIVA, $M_{:}$: KUKI, K: MIELKE, $M_{\text {: }}$ VENTRELLA, $M_{*}$ : GALVÃO M.; PINTO, L. Key leaf traits indicative of photosynthetic plasticity in tropical tree species. Trees, v. 29, n. 1, p. 247-258, 2015.

DUPUTIÉ, A.; RUTSCHMANN, A.; RONCE, O: CHUINE, I. Phenological plasticity will not help all species adapt to climate change. Global Change Biology, v. 1, n. 8, p. 3062-3073, 2015

DURIGAN, G.; SILVEIRA, E. R. Recomposição de mata ciliar em domínio de cerrado, Assis, SP. Scientia Forestalis, v. 56, n. 1, p. 135-144, 1999.
GIGNOUX, J., KONATÉ, S., LAHOREAU, G.; LE ROUX, X.; SIMIONI, G. Allocation strategies of savanna and forest tree seedlings in response to fire and shading: outcomes of a field experiment. Scientific Report, v. 6. n. 38838, p. 1-15, 2016.

GOLDSMITH, G. R.; MATZKE, N. J.; DAWSON, T. E. The incidence and implications of clouds for cloud forest plant water relations. Ecology Letters, v. 16, n. 3, p. 307-314, 2013

GRATANI, L. Plant Phenotypic Plasticity in Response to Environmenta Factors. Advances in Botany, v. 2014, n. 1, p. 1-17, 2014

GUAN, K.; PAN, M.; LI, H.; WOLF, A.; WU, J.; MEDVIGY, D.; CAYLOR, K. K SHEFFIELD, J.; WOOD, E. F.; MALHI, Y.; LIANG, M.; KIMBALL, J. S.; SALESKA, S R.; BERRY, J.; JOINER, J.; LYAPUSTIN, A. I. Photosynthetic seasonality of global tropical forests constrained by hydroclimate. Nature Geoscience, v. 8, n. 2 p. 284-289, 2015

INMET - Instituto Nacional de Meteorologia, 2017. Banco de Dados Meteorológicos para Ensino e Pesquisa. Estação 83464: Jataí/GO. Available at: http://www.inmet.gov.br/portal/index.php?r=bdmep/bdmep. Accessed in: January 28th 2017

KING, D. A.; MAINDONALD, J. H. Tree architecture in relation to leaf dimensions and tree stature in temperate forest seedlings. Journal of Ecology, v. 87, n. 6, p. 1012-1024, 1999

KLINGENBERG, C. P.; DUTTKE, S.; WHELAN, S.; KIM, M. Developmenta plasticity, morphological variation and evolvability: a multilevel analysis of morphometric integration in the shape of compound leaves. Journal of Evolutionary Biology, v. 25, n. 1, p. 115-129, 2012

KURSAR, T. A. COLEY, P. D. Convergence in defense syndromes of young leaves in tropical rainforests. Biochemical Systematics and Ecology, v. 21, $n$ 1, p. 929-949, 2003

LAMBERS, H.; CHAPIN III, F. S.; PONS, T. L. Plant Physiological Ecology Springer-Verlag, 1998. 604p.

LAWLOR, D. W.; CORNIC, G. Photosynthetic carbon assimilation and associated metabolism in relation to water deficits in higher plants. Plant Cell and Environment, v. 25, n. 2, p. 275-294, 2002.

LIN, C: POPESCU, S. C: HUANG, S. C. CHANG, P. T: WEN, H. L. A novel reflectance-based model for evaluating chlorophyll concentrations of fresh and water-stressed leaves. Biogeosciences, v. 12, n. 1, p. 49-66, 2015.

MARENCO, R. A. CAMARGO, M. A. B: ANTEZANA-VERA, S. A: OLIVEIRA M. F. Leaf trait plasticity in six forest tree species of central Amazonia Photosynthetica, v. 55, n. 4, p. 679-688, 2017.

MENDES, K. R.: MARENCO, R. A.: DOS SANTOS MAGALHÃES, N. Crescimento e eficiência fotossintética de uso do nitrogênio e fósforo em espécies florestais da Amazônia na fase juvenil. Revista Árvore, v. 37, n. 4, p. 707-16, 2013

NASCIMENTO, K. C.; PASTORINI, L. H.; ROMAGNOLO, M. B.; DE SOUZA, L. A Do Eugenia hiemalis seedling leaves under different light conditions develop phenotypic plasticity? Plant Ecology, v. 216, n. 11, p. 1571-1581, 2015

NICOTRA, A. B.; ATKIN, O. K.; BONSER, S. P.; DAVIDSON, A. M.; FINNEGAN E. J.; MATHESIUS, U.; POOT, P.; PURUGGANAN, M. D.; RICHARDS, C. L. VALLADARES, F.; VAN KLEUNEN, M. Plant phenotypic plasticity in a changing climate. Trends in Plants Science, v. 15, n. 12, p. 684-692, 2010.

OLIVEIRA-FILHO, A. T.; RATTER, J. A. Vegetation physiognomies and woody flora of the cerrado biome. In: OLIVEIRA, P. S.; MARQUIS, R. J. The cerrados of Brazil: ecology and natural history of a Neotropical savanna. Columbia University Press, 2002. p. 91-120.

RIBEIRO, J. F: WALTER, B. M. T. As principais fitofisionomias do bioma Cerrado. In: SANO, S. M.; ALMEIDA, S. P.; RIBEIRO, J. F. Cerrado: ecologia e flora. EMBRAPA Cerrados, 2008. p. 151-212.

ROZENDAAL, D M A : HURTADO, V $\mathrm{H}$ : POORTER, L Plasticity in leaf traits of 38 tropical tree species in response to light, relationships with light demand and adult stature. Functional Ecology, v. 20, n. 2, p. 207-216, 2006

SANCHES, M. C: MIELKE, M. S: SOUZA, C. S. D. D: VIEIRA, A. J. D: LOPES M. M. M.; BARBOSA J. M. Morfologia foliar de indivíduos jovens e adultos de Caesalpinia echinata Lam. numa floresta semidecídua do Sul da Bahia. Revista Árvore, v. 33, n. 5, p. 885-893, 2009

SCOPEL, I.; SILVA, M. R. Erodibilidade no estado de Goiás. 2001. Uniciência v. 8, n. 1, p. 123-132, 2001

SILVA, N. M. DA; ANGEOLETTO, F.; SANTOS, J. W. M. C.; PARANHOS FILHO A. C.; VACCHIANO, M. C.; BOHRER, J. F. C.; CANDIDO, A. K. A. A. The negative 
influences of the new Brazilian forest code on the conservation of riparian forests. European Journal of Ecology, v. 3, n. 2, p. 116-122, 2017.

VALLADARES, F.; MATESANZ, S.; GUILHAUMON, F.; ARAÚJO, M. B.; BALAGUER, L: BENITO-GARZON, M: CORNWELL, W: GIANOLI, E: VAN KLEUNEN, M. NAYA, D. E.; NICOTRA, A. B.; POORTER, $H_{i ;}$ ZAVALA, M. A. The effects of phenotypic plasticity and local adaptation on forecasts of species range shifts under climate change. Ecology Letters, v. 17, n. 11, p. 1351-1364, 2014.
VALLADARES, F.; WRIGHT, S. J.; LASSO, E.; KITAJIMA, K.; PEARCY, R. W. Plastic phenotypic response to light of 16 congeneric shrubs from a Panamanian rainforest. Ecology, v. 81, n. 7, p. 1925-1936, 2000

ZIMBRES, B.; SHIMBO, J.; BUSTAMANTE, M.; LEVICK, S.; MIRANDA, S.; ROITMAN I.; SILVERIO, D.; GOMES, L.; FAGG, C.; ALENCAR, A. Savanna vegetation structure in the Brazilian Cerrado allows for the accurate estimation of aboveground 458, n. 15 , p. $1-11,2020$ 